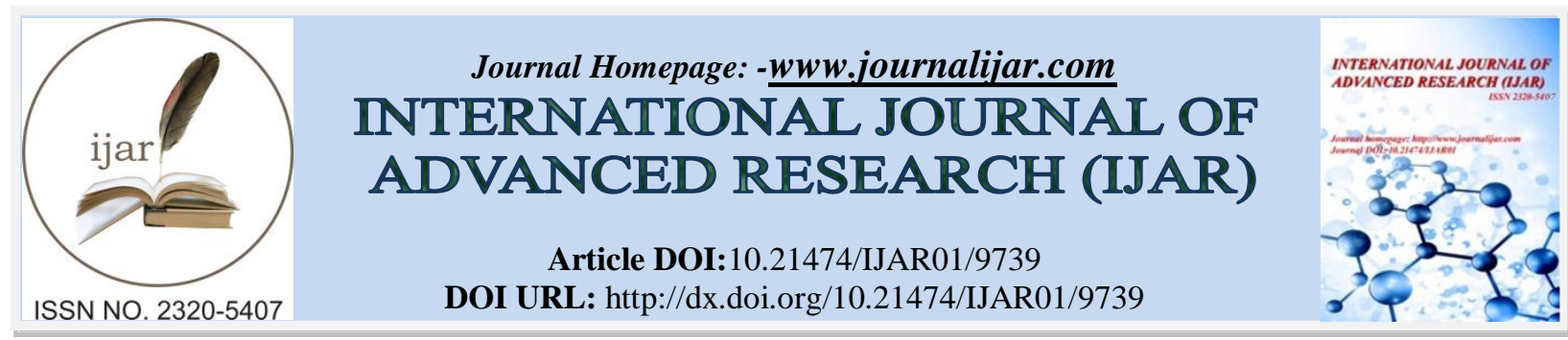

RESEARCH ARTICLE

\title{
ANALYSIS OF FACTORS AFFECTING OCCUPATIONAL SAFETY INDONESIAN NURSES WHO WORK IN QATAR.
}

\section{Dudang Aliansyah ${ }^{1}$,Syahfirin Abdullah ${ }^{2}$ and Kohar Sulistyadi ${ }^{3}$.}

1. Student Magister Program Study Occupational Health, Safety and Environment, Post Graduate School, Sahid University Jakarta.

2. Lecture of Post Graduate School, Sahid University Jakarta

\section{Manuscript Info}

Manuscript History

Received: 12 July 2019

Final Accepted: 14 August 2019

Published: September 2019

Key words:-

OHS Knowledge, OHS Behavior, OHS

Culture, Work Environment, Work

Safety, Nurses, SEM PLS.

\begin{abstract}
The main objective of this research is to analyze the factors that influence the safety of Indonesian nurses working in Qatar. The population in this study were 58 nurses, while the sample taken was 43 respondents who were chosen at random sample. The validity test and the reliability test of the variable indicator questions using SmartPLS version 3.2 with the requirements to meet the outer model, while testing the hypothesis using testing the structural model (inner model) using the SmartPLS program version 3.2 The results showed that the variable indicator question items had met the criteria of validity and reliability. Test the validity of the loading factor, cross loading, AVE values indicate that the instrument is valid. Reliability tests that were tested using composite reliability and Cronbach's Alpha met the requirements. Furthermore, hypothesis testing using SmartPLS shows that the Occupational Safety and Health (OSH) knowledge of nurses has no effect on the work environment and the work safety of nurses. The nurse's OSH behavior has a positive and significant effect on the work environment and the work safety of nurses. The OSH culture of nurses has a positive and significant effect on the work environment and the work safety of nurses.
\end{abstract}

Copy Right, IJAR, 2019,. All rights reserved.

\section{Introduction:-}

The success of implementing OSH Management System in a company can be seen from one of the objectives of its application, namely to reduce the occurrence of accidents in the workplace. In the field based on the BPJS report the number of accidents that occurred in 2017 was 123,000 case, in the following year, namely 2018 as many as 173,105 there were increase of around 40\% (Sign Safety.co.id 2019).

Knowledge is the result of knowing and this happens after people do sensing certain objects. Sensing occurs through the five senses, namely vision, hearing, smell and feeling. Most knowledge is obtained through the senses of hearing and vision (Notoatmojo 2007). Knowledge of OSH is very important, because with increasing knowledge there will be improvements in employee behavior in maintaining occupational safety and health. This approach is important to suppress incidents caused by unsafe behavior (Ramli, 2013).

Corresponding Author:-Dudang Aliansyah.

Address:-Student Magister Program Study Occupational Health, Safety and Environment, Post Graduate School, Sahid University Jakarta. 
Behaviour is taking part very important in occupational safety because generally the caused of occupational accident by unsafe behavior and unsafe equipment (Chinda, 2014). Improving unsafe work behavior, can no doubt help people to control and minimize costs and improve operational efficiency in long-term goals.

Culture according to The Confederation of British Industry is very simple, is "the way we do things arround here" the way we do things here, (Stranks, 2007). Organizational culture is important because it is the habits that occur in an organizational hierarchy that represent behavioral norms that are followed by all members of the organization. Maintaining an organizational culture will have an impact on the work environment and work safety so that all employees will carry out their duties in accordance with the company's vision and mission.

The work environment is a very important component when employees carry out work activities (Sunyoto, 2012). By paying attention to a good work environment or creating working conditions that are able to provide motivation to work, it will have a good influence on employee performance at work.

Employee safety is affected by complex causes, according to Watcher and Yurio (2014), one of the factors that can affect the safety performance of employees is the practice of OSH Management System (OSHMS) in organizations or companies. Good practice of OSHMS will have a positive effect on work safety.

Oil and gas companies (oil and gas) are process industries, according to Ramli (2017) Process industries are the highest cause of accidents compared to other types of industries. Accidents in various forms of industrial processes such as fire, pollution, explosion, poisoning, work accidents and environmental disturbances.

Indonesian nurses working in Qatar number are 58 people (Qatar DPLN PPNI, 2018). They work in several companies in Qatar. Most Indonesian nurses work in oil and gas companies, so that they are also like other workers in other departments who will be exposed to the risks and dangers caused by their work or the circumstances of their work environment.

The results of Mahfud's (2010) study, describing occupational accidents when viewed in terms of the use of personal protective equipment, the most frequent workplace accidents were nurses who used to use personal protective equipment namely 18 people $(21.7 \%)$ out of 23 respondents.

Puji's research (2016) it was found that work safety did not affect productivity with p-value $(0.467>0.05)$. Then occupational health has an effect on productivity with a p-value $(0.002<0.05)$. With these results it means that occupational health has the most influence on work productivity, thus the second hypothesis can be supported. The results obtained variables that have a causal relationship to the incidence of work accidents, namely the attitude of $p$ value 0.001 , training $\mathrm{p}$ value 0.001 and promotion $\mathrm{p}$ value 0.001 and the confounding is the knowledge variable on the training variable. The conclusion in this study is to make the implementation of OSH the most important part for nurses.

Sangaji research results (2017) with the title Analysis of the factors that affect employee safety at PT. Citra Interlindo Bekasi, there is an influence between OSH knowledge on the work environment by $25.7 \%$, there is an influence between OSH behavior on the work environment by $64.2 \%$, there is no influence between OSH culture on the work environment by $5.9 \%$, there is an influence between OSH knowledge on employee safety at $53.8 \%$, there is an influence between OSH behavior on employee safety at $36.4 \%$, there is a direct influence between OSH culture on employee safety at $17.9 \%$, there is a direct influence between the work environment on employee safety at $74.7 \%$.

Putri's research, Santoso, Rahayu (2018) obtained variables that have a causal relationship to the incidence of workplace accidents, namely $\mathrm{p}$ value 0.001 , training $\mathrm{p}$ value 0.001 and promotion $\mathrm{p}$ value 0.001 and the confounding is the knowledge variable on the training variable. The conclusion in this study is to make the implementation of OSH the most important part for nurses. Suggestions to the hospital together with the OSH Hospital committee in order to increase nurses' knowledge about OSH through regular socialization, training, and maintenance room meetings.

Accidents due to work in Clinic X Qatar, in the last three years there was an increase from 7 cases in 2016 to 10 cases in 2018, also supported by data from information obtained at one of the clinics in Qatar from 34 nurses in 
December 2018 experienced musculoskeletal disorder (MSD's) (5 nurses), knee pain ( 2 nurses), long absences due to surgery (2 nurses).

The purpose of this study is to analyze the affect of OHS knowledge, OHS behavior, OHS culture to the work environment and work safety of Indonesian nurses who work in Qatar.

\section{Literature Review \\ OSH Knowledge}

Knowledge is the result of knowing and this happens after people do sensing certain objects. Sensing occurs through the five senses, namely vision, hearing, smell and feeling. Most knowledge is obtained through the senses of hearing and vision (Notoatmojo 2007). Knowledge of OSH is very important, because with increasing knowledge there will be improvements in employee behavior in maintaining occupational safety and health. This approach is important to suppress incidents caused by unsafe behavior (Ramli, 2013). Work safety is a series of businesses to create a safe and secure atmosphere for employees (Suma'mur, 2009). Occupational safety and health is a process to create a safe and peaceful work environment so that employees avoid the dangers that surround them related to work.

\section{OSH Behavior}

The key element in safety is behavior improvement (safety behavior). This approach is important in suppressing incidents caused by unsafe behavior (Ramli, 2013). Behavior improvement is not an easy thing and is carried out in a planned manner by implementing work safety programs, especially those related to the improvement of unsafe behavior. Safety Behavior is the behavior of workers shown by obeying the regulations in the company in carrying out their work (Agiviana, 2015). Safety behavior according to Neal and Griffin is defined as safety-oriented behavior that is applied in daily work (Ingtyas\&Hadi, 2015).

\section{OSH Culture}

The definition of culture according to The Confederation of British Industry is very simple, namely the way we do things here, (Stranks, 2007). Organizational culture is important because it is the habits that occur in an organizational hierarchy that represent behavioral norms that are followed by all members of the organization. Maintaining an organizational culture will have an impact on the work environment and work safety so that all employees will carry out their duties in accordance with the company's vision and mission. Robbins \& Judge, (2016) explains that the characteristics referred to aspects of work culture include: 1. Discipline in carrying out tasks; 2. Openness of information from business partners for the benefit of the organization; 3. Respect with colleagues, superiors and consumers; 4. Able to collaborate with partners in achieving organizational goals and targets. In today's era culture has penetrated into various fields of means such as computer software, culture works as a software tool for humans that plays an important role in shaping ways to do thinking and acting.

\section{Work Environment}

The work environment is a very important component when employees carry out work activities (Sunyoto, 2012). By paying attention to a good work environment or creating working conditions that are able to provide motivation to work, it will have a good influence on employee performance at work. According to Sedarmayanti (2006) The work environment is all tool tools and materials faced by the surrounding environment where a person works, his working methods and work arrangements both as individuals and as a group. The working environment conditions are said to be good or appropriate if humans can carry out activities optimally, healthy, safe and comfortable.

\section{Work Safety}

Work safety concerns all processes of labor protection against the possibility of hazards arising in the work environment (Swasto, 2011). Lambrie (2010) defines, as a field of activity aimed at preventing all types of accidents related to the environment and work situations.

From some of the definitions above, the writer can conclude that work safety is a field of activity that contains the process of protecting workers from the possibility of accidents from environmental hazards and work situations. According to Mangkunegara (2014), the factors that cause occupational accidents are: The state of the work environment, air regulation, lighting settings, use of work equipment, physical and mental conditions of employees. 


\section{Hypothesis}

The hypothesis used in this study are:

1. H1: There is an influence between OSH knowledge on the work environment.

2. H2. There is an influence between OSH knowledge on work safety.

3. H3: There is an influence between OHS behavior on the work environment

4. H4. There is an influence between OSH behavior on work safety.

5. H5: There is an influence between OSH culture on the work environment.

6. H6: There is an influence between OSH culture on work safety.

7. H7: There is an influence between the work environment on work safety.

\section{Method:-}

This research is included in the category of explanatory research which aims to explain the influence of certain relationships among the variables specified in a study. According to Sugiyono (2011) the research variable is an attribute or the nature or value of people, objects, or activities that have certain variations determined by researchers to be studied and then conclusions drawn.

From the proposed hypothesis research variables are determined. The variables in this study are exogenous variables and endogenous variables, which are described as follows: Independent variables (endogenous variables) are variables that influence or are the cause of changes or the emergence of dependent / endogenous variables (Sugiyono, 2011). In this study the exogenous variables are knowledge of OSH (X1) and behavior of OSH (X2) and culture of OSH (X3). Dependent variables (endogenous variables) are variables that are influenced or which are due to the existence of independent variables / exogenous variables (Sugiyono, 2011). In this study endogenous variables are work environment (Y1) and work safety (Y2).

From these variables can be determined indicators and research instruments and sample designs used. The next step is to collect data through questionnaires. The collected data is then tested first with validity and reliability testing. The analysis technique used is the SEM-PLS (Structural Equition Modeling-Partial Least Square). The results of subsequent data analysis are presented and interpreted and the final steps are given conclusions and suggestions.

\section{Analysis Tool}

In this study the data analysis technique will use the SEM (Structural Equation Model) technique with the Partial Least Sequare (PLS) approach as the basis for the hypotesis test. Ghozali (2008) explains PLS is helping researchers to predict results. The formal model defines latent variables as linear aggregates of the indicators. The weight estimate to create a score component for latent variables is based on how the inner model (the structural model that connects latent variables) and the outer model (the measurement model that is the relationship between indicators and their constructs) is specified. The result is the residual variance of the dependent variable.

The analysis of partial least square (PLS) is a multivariate statistical technique that makes comparisons between multiple dependent variables and multiple independent variables. PLS is a variant-based SEM statistical method designed to complete multiple regression when specific problems occur in the data, such as small research sample sizes, missing values and multicollinearity (Jogiyanto, 2011).

Partial Least Square (PLS) SEM is an alternative approach that shifts from a covariance-based SEM approach to a variant based (Ghozali, 2014). Covariance-based SEM generally tests causality or theory while PLS is more predictive. In modeling with prediction purposes it has consequences that testing can be carried out without a strong theoretical basis, ignoring some assumptions and parameters of accuracy of the prediction model seen from the coefficient of determination (Jogiyanto, 2009). Structural model testing in PS was carried out with the help of SmartPLS software ver 3.2.6 for Windows. Steps that must be done in Partial Least Square (PLS) which include:

\section{Designing a measurement model (Outer Model)}

The design of the measurement model (outer model) in PLS is very important because it is related to whether the indicators are reflexive or formative. The outer model defines how each indicator block relates to other variables. The reflexive model is often referred to as the principal factor model, which means that the manifest variable is influenced by latent variables, while the formative model is the opposite of the reflexive model where the formative model assumes that the manifest variable influences latent variables. The direction of the causality relationship flows from the manifest variable to the latent variable. 


\section{Designing structural models (Inner Model)}

The structural model in PLS is evaluated using $\mathrm{R}^{2}$ for endogenous constructs, path coefficients, or $\mathrm{t}$-values for each path to test the significance between constructs in the structural model. $\mathrm{R}^{2}$ value is used to measure the level of variance of changes in exogenous variables to endogenous variables, where the higher the value of $R^{2}$ means the better the prediction model of the proposed research model, but $\mathrm{R}^{2}$ is not an absolute parameter in measuring the accuracy of prediction models because the basis of theoretical relationships is the most important parameter for explain the causality relationship. So, to test the validity and reliability of variables based on PLS output, the assessment criteria are as follows:

\section{Output Model Test Criteria:}

Outer Model (measurement model)

Discriminant Validity is the value of cross loading correlation with its latent variables must be greater than the correlation with other latent variables. Average Variannce Extracted (AVE) The AVE value must be >0.5. Composite Reliability Good composite reliability value if it has a value of $>0.7$. Cronbach's alpha Cronbach's alpha value is good / reliable if > 0.6. Source: Jogiyanto (2009)

\section{Inner model (structural model)}

The structural model in PLS is evaluated using R2 for the dependent construct, the path or t-values coefficient values for each path to test the significance between constructs in the structural model. R2 value is used to measure the degree of variance in changes in the independent variable on the dependent variable. The higher the value of R2 means the better the prediction model of the proposed research model (Jogiyanto, 2009).

The value of the path coefficient or inner model shows the level of significance in testing the hypothesis. The score for the path or inner model coefficient shown by the T-statistic value must be above 1.96 for the two tailed hypothesis, and above 1.64 for the one-tailed hypothesis for testing hypotheses at alpha 5 percent and 80 percent power (Hair, et al in Jogiyanto, 2009).

The criteria for out put PLS needed for the interpretation of inner models are as follows: Output Model Test Inner Model Criteria (Hypothesis Test) $\mathrm{R}^{2}$ for endogenous latent variables. Parameter coefficients and $\mathrm{T}$-statistics Estimated values for path relationships in the structural model must be significant, which can be obtained by bootstrapping procedures. Source: Jogiyanto (2009).

The significance test of the effect of exogenous variables was carried outby comparing the p-value to $\alpha$ (in this study using 0.05 ). If $\mathrm{p}$-value $<0.05$, the exogenous variable has a significant effect on endogenous variables and vice versa. If p-value $>0.05$, the exogenous variable does not have a significant effect on endogenous variables. (Ghozali, 2014)

\section{Population and Samples}

According to the Qatar DPLN PPNI report that until October 2018, there were 58 Indonesian nurses who were still working in Qatar, so all populations would be sampled (total sampling). Boring Sampling / Total Sampling is a sample that represents the number of population (J.Noor, 2011).

\section{Result And Discussion:- General description}

This research was conducted on the community of Indonesian nurses working in Qatar who generally work in oil and gas companies, and there are also a small number working in private hospitals or clinics. The study was conducted on May 1, 2019 until May 31, 2019 with as many respondents as 43 people. This research aims to analyze the factors that affect the safety of nurses who work in Qatar.

This research was conducted by distributing questionnaires to 58 Indonesian nurse members working in Qatar. From the scattered questionnaires only 43 were returned to the researcher and fulfilled the requirements for inclusion and exclusion of the study so that they could be used as data for processing.

\section{Characteristics of Respondents}

The respondents of this study were 43 employees, namely Indonesian nurses who worked in Qatar. Based on the sex of the respondents the most were men, namely 40 people (93\%) and women as many as 3 people (7\%). In general, 
men are stronger than women and are expected to have better productivity or performance than women, because men are expected to have more enthusiasm and energy.

Based on the level of education, the highest number of education is Bachelor 23 people (53.5\%) followed by Diploma 18 people (41.8\%) and Magistar 2 people (4.7\%). The level of education can be used as an indicator of the ability of employees in thinking and this initiative. The higher level of education is expected to be able to improve or improve a more systematic mindset because it combines the breadth of knowledge and maturity of thinking so that performance is better.

\section{Test Measurement Model (Outer Model)}

Validity and reliability tests were carried out on this model, with the Corfirmatory Factor Analysis (CFA) method adjusting to the data analysis method that will be used to test the hypothesis that is PLS Based - SEM. The criterion that the indicator or question item is valid when the value of the loading factor is $>0.70$ and is reliable in compiling the dimensions of the variable when the Cronbachs Alpha value is $>0.70$ or Composite Reliability> 0.70 .

Table 1:-

\begin{tabular}{|c|c|c|c|c|c|}
\hline & OSH Knowledge & OSH Behavior & OSH Culture & $\begin{array}{c}\text { Work } \\
\text { Environment }\end{array}$ & $\begin{array}{l}\text { Work } \\
\text { Safety }\end{array}$ \\
\hline $\begin{array}{l}\mathrm{X} 1.1 \\
\mathrm{X} 1.2 \\
\mathrm{X} 1.3 \\
\mathrm{X} 1.4 \\
\mathrm{X} 1.5\end{array}$ & $\begin{array}{l}0.835 \\
0.827 \\
0.911 \\
0.912 \\
0.859\end{array}$ & & & & \\
\hline $\begin{array}{l}\mathrm{X} 2.1 \\
\mathrm{X} 2.2 \\
\mathrm{X} 2.5\end{array}$ & & $\begin{array}{l}0.648 \\
0.941 \\
0.755\end{array}$ & & & \\
\hline $\begin{array}{l}\text { X3.1 } \\
\text { X3.2 } \\
\text { X3.3 } \\
\text { X3.4 }\end{array}$ & & & $\begin{array}{l}0.862 \\
0.886 \\
0.880 \\
0.824\end{array}$ & & \\
\hline $\begin{array}{l}\text { Y1.1 } \\
\text { Y1.2 } \\
\text { Y1.3 } \\
\text { Y1.4 } \\
\text { Y1.5 }\end{array}$ & & & & $\begin{array}{l}0.901 \\
0.804 \\
0.777 \\
0.857 \\
0.908\end{array}$ & \\
\hline $\begin{array}{l}\text { Y2.1 } \\
\text { Y2.2 } \\
\text { Y2.3 } \\
\text { Y2.4 } \\
\text { Y2.5 }\end{array}$ & & & & & $\begin{array}{l}0.786 \\
0.835 \\
0.765 \\
0.878 \\
0.888\end{array}$ \\
\hline
\end{tabular}

Source: Result of Run Smart PLS

Table 2:-Reliabilitas and Validitas Construct

\begin{tabular}{|r|c|c|c|}
\hline & Cronbachs Alpha & Composite realibility & AVE \\
\hline OSH Knowledge & 0.923 & 0.939 & 0.757 \\
\hline OSH Behavior & 0.745 & 0.845 & 0.646 \\
\hline OSH Culture & 0.887 & 0.922 & 0.747 \\
\hline Work Environment & 0.904 & 0.929 & 0.724 \\
\hline Work Safety & 0.888 & 0.918 & 0.692 \\
\hline
\end{tabular}

Source: Result of Run Smart PLS 


\section{OSH Knowledge Variable}

The OSH knowledge variable is measured by 5 manifests. Table 1 and Table 2 show that all OSH knowledge manifest variables are valid because the values of all manifest loading factors are $>0.70$, and are reliable because all manifests have Cronbachs Alpha values> 0.70 and strengthened Composite Reliability>0.70.

\section{OSH Behavior Variable}

The OSH behavior variable is measured by 5 manifests. Table 1 shows that all indicators are valid, after two invalid indicators are removed, namely manifest 3 (X2.3) and manifest 4 (X2.4) because the value of the loading factor is $<0.70$ so that the two manifests cannot be used again for further analysis. Reality test results Table 2 shows that all OSH behavior manifest variables are reliable because all manifests have Cronbachs Alpha values> 0.70 and strengthened Composite Reliability> 0.70 .

\section{OSH Culture Variable}

OSH Culture variable is measured by 5 manifests. Table 1 shows that all indicators are valid, after one invalid indicator is removed, namely manifest 5 (X3.5) because the loading factor value is $<0.70$ so that the manifest cannot be used again for further analysis. Reality test results Table 2 shows that all K3 behavior manifest variables are reliable because all manifests have Cronbachs Alpha values>0.70 and strengthened Composite Reliability>0.70.

\section{Work Environment Variable}

Work environment variables are measured by 5 manifests. Table 1 and Table 2 show that all work environment manifest variables are valid because the loading factor values of all manifests are $>0.70$ and are reliable because all manifests have Cronbachs Alpha values> 0.70 and strengthened Composite Reliability> 0.70 .

\section{Work Safety Variabe}

Work safety variables are measured by 5 manifests. Table 1 and Table 2 show that all work Safety manifest variables are valid because the loading factor values of all manifests are $>0.70$ and are reliable because all manifests have Cronbachs Alpha values>0.70 and strengthened Composite Reliability>0.70.

\section{Structural Model Test (Evaluation Inner Model)}

After testing or evaluating the measurement model is met, then the next test is carried out on the structural model. Structural model testing includes testing of terminated coefisient values $\left(\mathrm{r}^{2}\right)$ and testing the significance of the effects of exogenous variables with endogenous variables ( $t$ test). The results of testing or evaluating the measurement model are as follows:

\section{Determination Coefficient $\left(\mathbf{R}^{2}\right)$}

The deterrence coefficient shows the goodness of fit with the actual situation. The closer to number one, the model is considered to be getting better. The result shows that the value of $\mathrm{R}^{2}$ in this research model is 0,777 which means that knowledge, behavior, culture and work environment have a weight of influence on work safety of $77.7 \%$, while $22.3 \%$ is influenced by other variables not included in this model.

\section{Significance and magnitude of the coefficient of structural models}

Significance test of the influence of exogenous variables OSH knowledge, OSH behavior, OSH culture on endogenous variables work environment and work safety is done by $\mathrm{t}$ test where the criterion is if the value of $\mathrm{t}$ count / statistics> t-table (1.96) then the exogenous variable has a significant effect on endogenous variables and vice versa if the value of t-count / statistics <t-table, then the exogenous variable has no significant effect on endogenous variables, significance test can also be done by comparing the p-value to $\alpha$ (in this study using 0.05 ). If $\mathrm{p}$-value $<0.05$, exogenous variables significantly influence endogenous variables and vice versa. If $\mathrm{p}$-value $>0.05$, exogenous variables have no significant effect on endogenous variables, Ghozali (2014).

The results of the analysis shows there are 3 coefficient relationships that have a significant effect between exogenous variables on endogenous variables, namely the OSH behavior to the work environment with a statistical T 2.389 and P-Value 0.017, OSH culture to the work environment with a statistical T 4.731 and a P-Value 0.000 and the work environment to work safety with a T statistical 4.362 and P-Value 0,000 and there are 4 coefficient relationships that have no effect between exogenous variables towards endogenous variables, namely OSH knowledge to the work environment with a statistical T 0.472 P-Value 0.637 , OSH knowledge to work safety with a 
statistical T 1.313 and P-Value 0.190, OSH behavior to work safety with T statistic 0.815 and P-Value 0.415 and OSH culture to work safety with T statistic 1.847 and P-Value 0.065

\section{Hypothesis}

H1. The effect of OSH knowledge on the work environment

The nurse's OSH knowledge does not affect the work environment with the original sample value of -0.036 , $\mathrm{T}$ statistic $0.472<1.960$ and $\mathrm{P}$-value $0.637>0.05$. The significance $(0.637)$ is greater than 0.05 .

\section{H2. The effect of OSH knowledge on work safety}

The nurse's OSH knowledge does not affect the safety of nurses with an original sample value of 0.100 , T statistics $1.313<1.960$, P-value $0.190>0.05$. Significance $(0.190)$ is greater than 0.05 .

\section{H3. The effect of OSH behavior on the work environment}

The nurse's OSH behavior directly has a significant positive effect on the nurse's work environment with an original sample value of 0.449 , T statistics of $2,389>1,960$ and $\mathrm{P}$-value of $0.017<0.05$. The significance $(0.017)$ is smaller than 0.05

\section{H4. The effect of OSH behavior on work safety}

The nurse's OSH behavior does not affect on the work safety of nurses with an original sample value of -0.081 , $\mathrm{T}$ statistic $0.815<1.960$, P-value $0.415>0.05$. The significance $(0.415)$ is greater than 0.05 .

\section{H5. The influence of OSH culture on the work environment}

The nurse's OSH culture directly has a significant positive effect on the nurse's work environment with an original sample value of $0.541, \mathrm{~T}$ statistic of $4.731>1,960$ and P-value of $0.00>0.05$. Significance $(0,000)$ is smaller than 0.05 .

\section{H6. The influence of OSH culture on work safety.}

The nurse's OSH culture does not affect on the occupational safety of nurses with an original sample value of 0.277 , T statistics $1.847<1.960$ and $\mathrm{P}$-value $0.065>0.05$. The significance $(0.065)$ is greater than 0.05 .

\section{H7. The effect of work environment on work safety}

The nurse's work environment directly has a significant positive effect on nurses' work safety with an original sample value of 0.679 , T statistic of $4.362>1,960$ and P-value of $0,000<0.05$. Significance $(0,000)$ is smaller than 0.05 .

\section{Conclusion:-}

The purpose of this study is to obtain or produce the value of the influence of the relationship between the variables of the characteristics of knowledge, behavior, culture on the work environment and work safety of Indonesian nurses who work in Qatar.

Data processing is done by partial least square structural equation model (PLS-SEM) and the software used is SmartPLS 3.2. From the PLS-SEM test results in this study, the following information can be obtained:

1. The OSH knowledge of nurses has no effect on the work environment and work safety of Indonesian nurses working in Qatar. Judging from the characteristics of education most respondents are Bachelor education $(53.5 \%)$ where respondents have quite high knowledge, but here illustrates that knowledge has no significant effect on the work environment, meaning it is necessary to increase efforts to develop human resources in terms of knowledge by carrying out training training and programs related to OSH routinely and continuously in order to increase the nurse's OSH knowledge.

2. The nurse's OSH behavior has a significant effect on the work environment and has no effect to work safety of Indonesian nurses working in Qatar. Judging from the educational characteristics of the respondent's minimum education respondents are Diploma level with categorized respondents have high enough knowledge, so that they will have good OSH behavior. Good OHS behavior will form a conducive work environment to maintain the work safety of employees.

3. The nurse's OSH culture has a significant effect on the environment and has no effect to work safety of Indonesian nurses working in Qatar. Judging from the educational characteristics of most respondents is Bachelor education (53.5\%) where the respondents have quite high knowledge, so they will have a good OSH 
culture. A good OSH culture will form a conducive work environment to maintain the safety of employees' work.

4. The work environment of nurses has a significant effect on the work safety of Indonesian nurses working in Qatar. Judging from the educational characteristics of the respondents, the minimum education of respondents is Diploma categorized respondents have high enough knowledge, so that it will be able to create a conducive work environment in order to maintain the work safety of the employees.

5. For the R Square model obtained is 0.777 or $77.7 \%$, then $77.7 \%$ of the variance in the work safety variables of Indonesian nurses working in Qatar are influenced by variables of knowledge, behavior, culture and environment while the rest are influenced by other factors.

\section{Recomendation}

Based on the results of the study, recommendations or suggestions can be made for nurses and companies in an effort to reduce work accident rates and improve work safety with influencing factors such as OSH knowledge, OSH behavior, OSH culture and work environment as follows:

1. In order to increase nurses' knowledge about OHS, pro-active nurses should take part in programs organized by companies in the OSH field, in the form of trainings, courses or e-learning with the aim of; a lot of information is expected to be absorbed by nurses in forming good understandings of OSH in carrying out their nursing duties.

2. To maintain and improve OSH behavior of nurses in carrying out their duties properly, nurses should behave in compliance with all policies implemented by the company and comply with all applicable regulations, so that nurses are expected always get good rewards from the company to minimize all penalties imposed by the company.

3. In order to improve the OSH culture of nurses in carrying out their duties, it is recommended to nurses to cultivate promotions related to OSH, with the aim of always instilling a good OSH culture of nurses so that the performance of the company is maintained properly, able to contribute to the company with healthy and strong competitiveness.

4. In order to improve the formation of a good and conducive working environment, it is advisable for nurses to always maintain cleanliness, order, security and comfort of the work environment, for example, always arrange work equipment neatly, adjust the room temperature and humidity accordingly, maintain noise so as not to disturb hearing of other employees during activities and always keeping the floor free from slippery.

\section{REFERENCE}

1. Agiviana AP. 2015.Analisis PengaruhPersepsi, Sikap, Pengetahuan Dan TempatKerjaTerhadapPerilakuKeselamatanKaryawan (StudiPada Perusahaan PT Muliaglass Container Division. [SkripsiIlmiah]. JurusanManajemenFakultasEkonimoka Dan BisnisUniversitasDiponegoro

2. Ari Andriyas Puji. 2016. Pengaruh Keselamatan dan Kesehatan Kerja Terhadap Produktivitas Menggunakan Structural Equation Modeling. Jurnal Fakultas Teknologi Industri Program Studi Teknik Industri UII 2016

3. Chinda, Thanwadee. 2014. Organizational Factors Affecting Safety Implementation in Food Companies in Thailand. International Journal of Occupational Safety and Ergonomics (JOSE) Vol. 20, No.2:213-215

4. Friend, A.M. and Khon, P.J. 2007. Fundamental Of Occupational Safety and Health. Fourth Edition. Goverment Institutes. Lanham, Maryland. Toronto.

5. Ghozali, Imam. 2014. Structural Equition Modeling, Metode Alternatif dengan Partial Least Square (PLS). Semarang: Badan Penerbit Universitas Diponegoro

6. Ghozali, Imam. 2008, Model Peramaan Struktural Konsep dan Aplikasi dengan Program Amos 16.0, Badan Penerbit UNDIP, Semarang.

7. https://en.wikipedia.org/wiki/Partial_least_squares_path_modeling. Accessed 29/01/2019

8. https://www.safetysign.co.id/news/404/Ini-Tahapan-tahapan-Penting-yang-Harus-Dilakukan-Dalam-AuditEksternal-SMK3). Accessed 10/06/2019.

9. Ingtyas, W. S. \& C. Hadi. (2015). Hubungan Model TuntutanKerjaSumberDayaKerjadenganPerilakuKeselamatanKerja. JurnalPsikologiIndustridanOrganisasi. Vol 04 No 2.

10. International Labor Organization ( ILO ). 2004. Kesehatan dan Keselamatan Kerja di Indonesia. Manila

11. Jogiyanto. 2009. Analisis dan Desain Sistem Informasi. Yogyakarta: Andi.

12. Jogiyanto, H. M., dan Abdillah, W. 2009. Konsep Dan Aplikasi PLS (Partial Least Square) Untuk Penelitian Empiris. Yogyakarta: Badan Penerbit Fakultas Ekonomi Dan Bisnis UGM

13. J. Stranks, 2007. Human Factors and Behavioral Safety. Butterworth Heinemann: ElseverLambrie, Irianto. 2010. Manajemen Sumber Daya Manusia. Yogyakarta: Laksbang Preesindo. 
14. Laporan Kegiatan Keperawatan Pusat Pelayanan Kesehatan X di Qatar, tahun 2018.

15. Laporan PPNI DPLN Qatar bahwa sampai Oktober 2018 Mahfud Burhami, 2010. Survey Kecelakaan Kerja Pada Perawat di RSU Salewangan Kabupaten Maros. UIN Alaudin Makasar.

16. Mangkunegara, Anwar Prabu AA. 2014. Manajemen Sumber Daya Manusia Perusahaan. Bandung: PT. Remaja Rosdakarya.

17. Mondy, Wayne R. \& Robert M. Noe. 2009. Human Resources Management Edisi ke -9. New Jrsey: Penerbit Prentice Hall.

18. Nazirah Riska, Yuswardi. 2017. Perilaku Perawat Dalam Penerapan Manajemen Kesehatan dan Keselamtan Kerja (K3) Di Aceh. Idea Nursing Jornal. Vol VIII No 32017.

19. Noor J. (2011), Metoda Penelitian. Edisi pertama. Jakarta: Kencana Prenada Media Group

20. Notoatmodjo.S.( (2007). Metodologi Penelitian Kesehatan, jakarta: Rineka Cipta.

21. OSHA, 2015. OSHA Safety and Health Program Management Guidelines. http://www.osha.gov

22. Ramli, Soehatman. 2010. Sistem Manajemen Keselamatan dan Kesehatan Kerja OHSAS 18001. Jakarta: Dian Rakyat.

23. Ramli, Soehatman. 2013. Smart Safety Panduan Penerapan SMK3 yang Efektif. 2013. Jakarta: Dian Rakyat.

24. Ramli, Soehatman. 2017. Manajemen Keselamatan Proses Berbasis Resiko. 2017. Yayasan Pengembangan Keselamatan, Prosafe Institute.

25. Ramli, Soehatman.2010. Pedoman Praktis Manajemen Risiko Dalam Perspektif K3 OHS Risk management. Jakarta: Dian Rakyat

26. Robbins, S.P., dan Judge, T.A., (2016) Organizational Behavior. Copyright by Pearson Education, Inc., publishing as Prentice Hall .

27. Ruswandi, Kusmawan \& Sutrisno. 2007. Prosedur Keamanan Keselamatan dan Kesehatan Kerja. Jakarta : Galia.

28. Sangaji A. (2017) Analisis faktor-faktor yang mempengaruhi keselamatan kerja karyawan pada PT. Citra Interlindo Bekasi. Tesis Universitas Sahid Jakarta

29. Sedarmayanti. 2006. Manajemen Sumber Daya Manusia dan Produktivitas Kerja. Jakarta : Mandar Maju

30. Sentya Putri, Santoso, Endang Purnawati Rahayu. 2018. Pelaksanaan Keselamatan dan Kesehatan Kerja Terhadap Kejadian Kecelakaan Kerja Perawat di Rumah Sakit.

31. Sucipto, Cecep Dani. 2014. Keselamatan dan Kesehatan Kerja. Jakarta : Penerbit PPM.

32. Sugiono,2012, Metodologi Penelitian Bisnis. Alafabeta. Bandung

33. Sugiyono. 2011. Metode Penelitian Pendidikan. Alafabeta. Bandung

34. Suma'mur PK, 2009. Hygiene Perusahaan dan Kesehatan Kerja . Jakarta: Gunung Agung.

35. Sunyoto, Danang. 2012. Manajemen Sumber daya Manusia. Yogyakarta: Center For Academic Publishing Service.

36. Swasto, Bambang. 2011. Manajemen Sumber Daya Manusia. Malang : UB Press.

37. Watcher J. K. Dan Patrick L. Yorio, 2014. A System of Safety Management Practices and Worker Engagement for Reducing and Preventing Accidents: An emphirical and Theoretical Investigation. Journal of Accident Analysis and Prevention 68 (2014):117-13. 